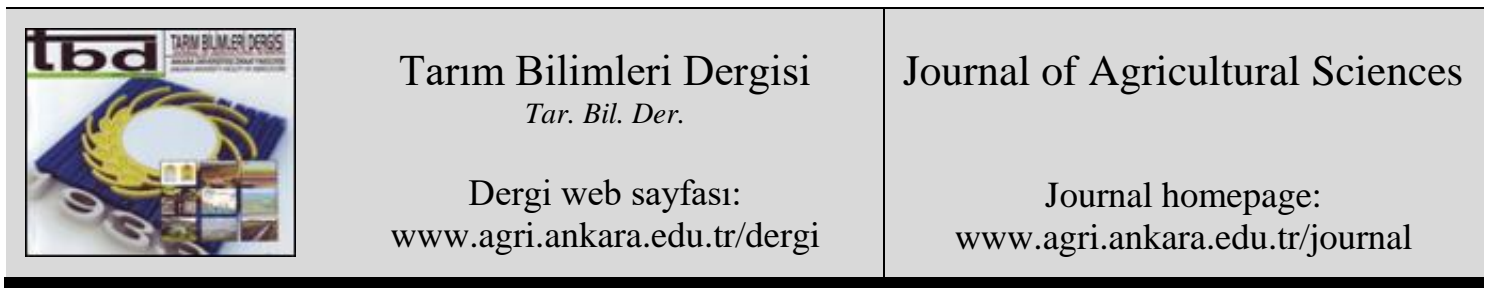

\title{
Insecticidal Efficacy and Repellency of Trans-Anethole Against Four Stored-Product Insect Pests
}

\author{
Mustafa ALKAN ${ }^{\mathrm{a}}$, Sait ERTÜRK ${ }^{\mathrm{a}}$ \\ $a_{\text {Plant Protection Central Research Institute, Ankara, TURKEY }}$
}

\author{
ARTICLE INFO \\ Research Article \\ Corresponding Author: Mustafa ALKAN, E-mail: alkan0101 @ gmail.com, Tel: +90 (312) 3445993 \\ Received: 18 July 2018, Received in Revised Form: 26 December 2018, Accepted: 04 January 2019
}

\section{AUTHORS ORCID ID}

(Mustafa ALKAN: 0000-0001-7125-2270), (Sait ERTÜRK: 0000-0001-9961-3955)

\begin{abstract}
In this study, it was investigated that repellency and insecticidal efficacy of trans-anethole of botanical origin on major stored product on pests species, namely Sitophilus granarius (L.) (Coleoptera: Curculionidae), Sitophilus oryzae (L.) (Coleoptera: Curculionidae), Tribolium confusum Jacquelin du Val (Coleoptera, Tenebrionidae) and Tribolium castaneum (Herbst) (Coleoptera, Tenebrionidae). Repellency effect was evaluated by choice test in petri dishes, while the mortality effect was examined by exposure to wheat treated at different concentrations, such as $1,2,3$, 4 , and $8 \mu \mathrm{L}$ trans anethole. In efficacy tests, after 72 hours exposure, the highest adult mortality was found on $T$. castaneum with a $60 \%$ mortality, while other test species showed no significant mortality. On the other hand,
\end{abstract}

repellency tests revealed varying degree of repellency depending on the application dose of trans-anethole. It was determined that $S$. granarius belongs to repellent class III, while all of the other species fall under repellent class IV. F1 progeny decreased as trans-anethole concentration increased, and in this context $8 \mu \mathrm{L}$ of trans-anethole is proved to be the optimal concentration causing maximum decrease in progeny production. Among the insect species tested, $T$. confusum was found to be the most sensitive to transanethole with $100 \%$ decrease in $\mathrm{F} 1$ progeny production. Our results indicate that trans-anethole can be used as a potential repellent for the control of major stored grain pests. Additionally, trans-anethole, by its contact efficacy, might be considered as a grain protectant against $S$. granarius, $S$. oryzae, $T$. confusum and $T$. castaneum.

Keywords: Apiaceae; Plant essential oil; Repellency; Progeny; Stored product insect

\section{Introduction}

(C) Ankara Üniversitesi Ziraat Fakültesi

Stored grains are often subjected to quality and quantity losses of varying magnitude during the storage (Boxall 2001; Ferizli \& Emekci 2010). Grain deterioration which caused by several biotic and abiotic factors can be occurred in various ways, such as germination, clumping, self-heating, burning, baking quality, color and many others (Amruta et al 2015). Among the biotic factors in stored grain, insects stand as the most important cause of deterioration that result in significant economic losses (Boxall 2001). Postharvest loss of grains caused by insect pests can be prevented or minimized through careful stored grain management. The most common and effective method against stored products pests is fumigation (Shaaya \& Kostyukovsky 2011). Synthetic fumigants such as methyl bromide, aluminum phosphide, sulphuryl fluoride, carbonyl sulphide, ethane nitrile, and ethyl format are currently being used in pest control (Bond 
1984; Taylor 1994; Villers et al 2010; Mutungi et al 2014). These chemicals, however, can pose risks to environment and human health, as in the example of methyl bromide, which is currently prohibited by the Montreal Protocol due to its ozone depletion potential. European Pesticide Regulation [(EC) No. 1107/200] is another restrictive policy instrument in effect for the prevention of hazardous chemical use. Therefore, there is a big demand for novel pest control approaches using less toxic substances. Among the alternative approaches, secondary plant metabolites has gained much attention (Taiz \& Zeiger 2002).

Secondary plant metabolites have behavioral and biological effects on insects are categorized in various classes (Güncan \& Durmuşoğlu 2004). The most effective compounds against insect pests are alkaloids, glycosides, phenols, terpenoids, tannins, and saponins (Shanker \& Solanki 2000). These compounds can play important roles in plant defense mechanisms against insects, such as toxicity, feeding cessation, repellency, locating prey or hosts by predators and parasitoids. Trans-anethole is a secondary metabolite which is synthesized from plants belonging to Apiaceae family, in particular. Bio-efficacy of plant essential oils and their major components against stored product insect pests are very well documented (Hikal et al 2017). Essential oils do not cause environmental pollution, do not leave residues unlike synthetic toxic chemicals, and are not dangerous to non-target organisms in nature (Regnault-Roger et al 2012). Moreover, fumigant activity of trans-anethole has been proven against major stored product insects in several studies (Shaaya et al 1991; Ho 2000; Mondal \& Khalequzzaman 2010). For these reason essential oils can be promising materials in the development of alternative plant protection products against stored product pests (Shaaya et al 1991; Shaaya et al 1993; Ho 2000; Huang et al 2000; Wang et al 2001; Karakoç et al 2006; Mondal \& Khalequzzaman 2010; Pimentel et al 2010).

In this study, insecticidal efficacy and repellency of trans-anethole against four major insect pests of stored products were investigated. In addition, inhibitory effect of trans-anethole on progeny production of the same insect species was also evaluated.

\section{Material and Methods}

\subsection{Insect rearing}

All of the test insects were obtained from laboratory colonies maintained continuously at the stored product pest laboratory of Directorate of Plant Protection Central Research Institute (Ankara, Turkey) since 2008. A rearing medium composed of a mixture of crushed soft wheat (Tritucum aestivum L.) and powdered dry yeast (Saccharomyces cerevisiae Hansen) (20:1 w/w) was used to rear Tribolium castaneum (Herbst) (Coleoptera, Tenebrionidae) and T. confusum Jacquelin du Val (Coleoptera, Tenebrionidae). For rearing Sitophilus granarius and S. oryzae (L.) (Coleoptera: Curculionidae) whole soft wheat kernels were used (Ertürk et al 2017).

\subsection{Contact toxicity of trans-anethole on grains}

Experiments were conducted according to the standards given in Ndomo et al (2008). Five different doses of $1,2,3,4$, and $8 \mu \mathrm{L}$ of trans-anethole (CAS number: $4180-23-8,99 \%$ ) were mixed with $1 \mathrm{~mL}$ of acetone and then each mixture was applied into $10 \mathrm{~g}$ wheat by using pipette and stirred with glass rod to ensure well mixture. In the control group, only $1 \mathrm{~mL}$ of acetone was applied to $10 \mathrm{~g}$ wheat. Treated wheat with transanethole solution at different doses was put under a fume cupboard for 5 minutes to evaporate the solvent and then transferred into jars, each of which contained 25 (one-day old) adult individuals of each species separately. The jars were kept in a climate chamber at $25 \pm 2{ }^{\circ} \mathrm{C}$ and $65 \%$ relative humidity (r.h.). The treatments were arranged randomized design with four replicates, each of which included the control group. After setting up the experiments, mortality counts for adults were made daily after treatment during following three days.

\subsection{Effect of trans-anethole on F1 progeny}

At the end of three days of contact toxicity tests, dead and live insects were removed from the treated wheat and the jars containing treated wheat only were retained at the same conditions for 60 days and at the end 
of 60 days $\mathrm{F} 1$ progeny adults were counted.

Inhibition rate was calculated by following formula.

$I R=\frac{C n-T n}{C n} * 100$

Where; \%IR, inhibition rate; $C \mathrm{n}$, number of newly emerged adults in untreated (control); $\mathrm{Tn}$, number of newly emerged insects in treated replicates.

\subsection{Repellent effect of trans-anethole}

McDonald et al (1970)'s procedure was followed for the repellent activity of trans-anethole. Accordingly, $9 \mathrm{~cm}$ diameter discs of Whatman No. 1 filter paper was used. One half of each disc was treated with 1,2, 3,4 , or $8 \mu \mathrm{L}$ of trans-anethole in $1 \mathrm{~mL}$ of acetone, while the other half treated by acetone only. After aerating filter paper discs for 5 minutes to evaporate solvent, 20 (one-day old) adult individuals of $T$. castaneum or S. granarius in each concentration were separately placed on filter paper discs in Petri dishes. The inner sides of Petri dishes were coated with Fluon ${ }^{\mathbb{B}}$ PTFE (AGC Chemicals Europe, Ltd) to prevent the insects escaping. The covers of the petri dishes were drilled $1 \mathrm{~mm}$ in diameter to ensure air circulation. Petri dishes then incubated for $2 \mathrm{~h}$ at $25 \pm 2{ }^{\circ} \mathrm{C}$ in the dark. At the end of $2 \mathrm{~h}$, Petri dishes were opened and insects were counted according to which half of the paper discs they were settled on.

Percentage repellency was calculated according to the formula below:

$P R=\frac{N c-N t}{N c+N t} * 100$

Where; PR, percentage repellency value; $\mathrm{Nc}$, number of insects in untreated (control) group; $\mathrm{Nt}$, number of insects in treated group

Average percentage repellency values were categorized according to 0-V scale of Juliana \& $\mathrm{Su}$ (1983). [Class 0 (PR< 0.1\%); Class I ( $\mathrm{PR}=0.1-20 \%)$; Class II ( $\mathrm{PR}=20-40 \%)$; Class III ( $\mathrm{PR}=40.1-60 \%)$; Class IV $(\mathrm{PR}=60.1-80 \%) ;$ Class V $(\mathrm{PR}=80.1-100 \%)]$

\subsection{Statistical analysis}

Prior the statistical analyses, percent mortality data obtained from the toxicity and repellency tests were transformed using arcsine transformation. The transformed data were then subjected to analysis of variance (ANOVA) followed by Tukey's multiple comparison test $(\mathrm{P}<0.05)$ using MINITAB $®$ Release 16 package program.

\section{Results and Discussion}

\subsection{Contact toxicity of trans-anethole on grains}

Each species showed different levels of susceptibility to trans-anethole (Figure 1). Tribolium castaneum was the most sensitive species to essential oil with $60.16 \%$ mortality when exposed to trans-anethole at 8 $\mu \mathrm{L}$ for $72 \mathrm{~h}$. Statistical analysis revealed that there were significant differences between doses $\left(\mathrm{F}_{(4,15)}=\right.$ 307.87; $\mathrm{P}<0.05$ ) Insecticidal efficacy of trans-anethole against $T$. castaneum increased with dose increases. The higher doses of trans anethole was not used for experiments, because of the odor residue problems on the treated product. The essential oil did not show any contact toxicity to $T$. confusum at any concentration rate tested throughout the exposure period. Toxicity effect on S. oryzae was also negligible with $8.67 \%$ mortality, at most, after 72 hours at the highest level of dosage $\left(\mathrm{F}_{(4,15)}=21.96 ; \mathrm{P}<0.05\right)$ (Figure 1).

Residual efficacy of plant essential oils as grain protectants was received less attention. In scientific arena, plant essential oils were rather used to evaluate their fumigant efficacy or contact toxicity by topical 
applications. Therefore, in this study, residual toxicity of trans-anethole against major stored-product insects on treated wheat grain were studied. Although no significant effect was obtained against test species except T. castaneum, our findings are contradictory with the previous studies (Karakoç et al 2006; Alkan \& Gökçe 2012).

\section{Mortality (\%)}

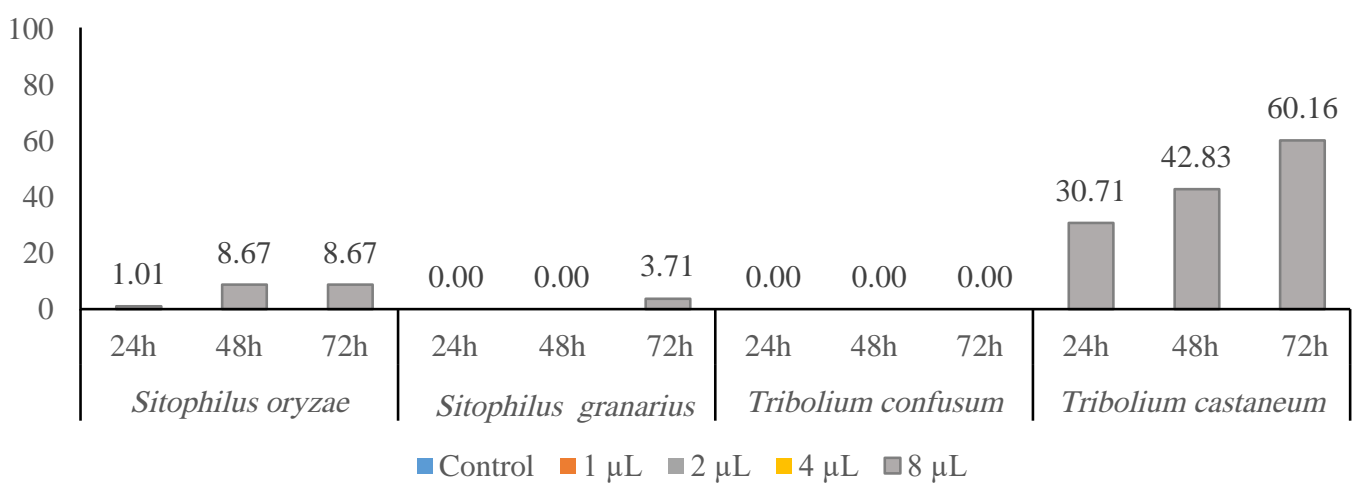

Figure 1- Mortality data of $S$. granarius, $S$. oryzae, $T$. confusum and $T$. castaneum exposed to wheat treated with trans-anethole at different rates $(\%)$

\subsection{F1 progeny assessment}

F1 progeny suppression of test insects was increased with the application dose increased (Figure 2 and 3 ). The highest suppression rate was observed in $T$. confusum with a $100 \%$ decrease in F1 progeny at $8 \mu \mathrm{L}$ of trans-anethole. Suppression rates in other species used in the experiments were as follows: T. castaneum (97.80\%); S. oryzae (94.19\%); and S. granarius (80\%). Overall, the desired level of F1 progeny suppression activity was reached at the concentration of $8 \mu \mathrm{L}$. Tapondjou et al (2002) determined that, S. granarius was exposed for $48 \mathrm{~h}$ to $0.8 \%$ or $6.4 \%$ of the dry ground leaves Chenepodium ambrosioides L. (Chenepodiaceae) as grain protectant. Both low and high doses of $C$. ambrosioides completely suppressed in treated whole wheat against progeny production of $S$. granarius. Tapondjou et al (2005), showed that the F1 production of $S$. zeamais was completely suppressed on grains treated with Eucalyptus saligna and Cupressus sempervirens L. (Cupressaceae) crude oil extracts at the doses of 75 and $100 \mu \mathrm{L} / 40 \mathrm{~g}$ grain respectively. Contrary to other studies, it is believed that the $8 \mu \mathrm{L}$ dose which provides $100 \%$ mortality in T. confusum, is due to the impurity of the crude essential oil composition used in other studies.

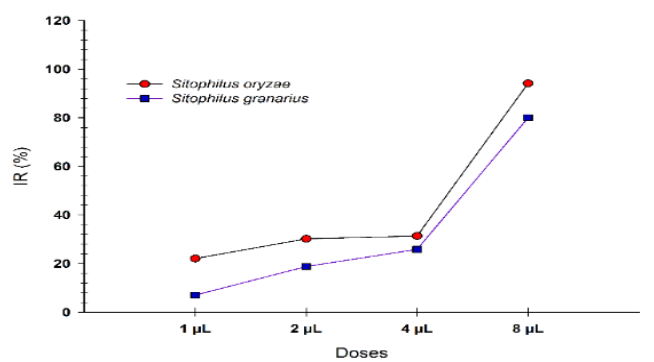

Figure 2- F1 progeny effect of Trans-anethole anetholeon S. granarius and S. oryzae

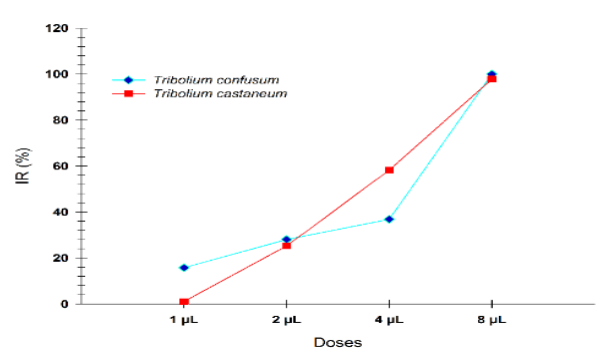

Figure 3- F1 progeny effect of Transon $T$. confusum and T. castaneum

\subsection{Repellent effect of trans-anethole}

Percentage repellency values increased as the concentration of trans-anethole increased (Table 1). PRs of four species at the lowest dose of $1 \mu \mathrm{L}$ and at the highest dose of $8 \mu \mathrm{L}$ of trans-anethole were, respectively, as follows: $S$. granarius, $12.5 \%$ and $97.5 \%\left(\mathrm{~F}_{(3,15)}=175.0 ; \mathrm{P}<0.05\right) ;$ S. oryzae, $47.5 \%$ and $95 \%\left(\mathrm{~F}_{(3,15)}=26.9\right.$; $\mathrm{P}<0.05) ; T$. confusum, $30 \%$ and $95 \%\left(\mathrm{~F}_{(3,15)}=25.33 ; \mathrm{P}<0.05\right) ;$. castaneum, $5 \%$ and $100 \%\left(\mathrm{~F}_{(3,15)}=59.9\right.$; $\mathrm{P}<0.05)$. 
Table 1- Repellency effects of Trans-anethole on test adults exposed to filter paper with four different concentrations for $2 \mathrm{~h}$

\begin{tabular}{lcccc}
\hline & \multicolumn{4}{c}{ Repellency $(\%) \pm$ SEM } \\
\cline { 2 - 5 } & Sitophilus granarius & Sitophilus oryzae & Tribolium confusum & Tribolium castaneum \\
\hline $1 \mu \mathrm{L}$ & $12.5 \pm 2.5 \mathrm{c}^{1}$ & $47.5 \pm 4.8 \mathrm{c}$ & $30.0 \pm 5.8 \mathrm{~b}$ & $5.0 \pm 2.1 \mathrm{~b}$ \\
$2 \mu \mathrm{L}$ & $17.5 \pm 4.8 \mathrm{c}$ & $57.5 \pm 2.5 \mathrm{bc}$ & $80.0 \pm 8.2 \mathrm{a}$ & $80.0 \pm 8.2 \mathrm{a}$ \\
$4 \mu \mathrm{L}$ & $77.5 \pm 2.5 \mathrm{~b}$ & $65.0 \pm 2.9 \mathrm{~b}$ & $95.0 \pm 5.0 \mathrm{a}$ & $90.0 \pm 5.8 \mathrm{a}$ \\
$8 \mu \mathrm{L}$ & $97.5 \pm 2.5 \mathrm{a}$ & $95.0 \pm 5.0 \mathrm{a}$ & $95.0 \pm 5.0 \mathrm{a}$ & $100.0 \pm 0.0 \mathrm{a}$ \\
\hline Average & $51.3 \pm 9.7$ & $66.3 \pm 4.9$ & $75.0 \pm 7.4$ & $68.8 \pm 9.9$ \\
\hline Repellency classes & III & IV & IV & IV \\
\hline 1, Different letters in the same column indicate statistically different from each other (Anova P<0.05, Tukey test)
\end{tabular}

Essential oils and their compounds were previously reported having potent repellency activity on storedproduct insects (Liu \& Ho 1999; Isman 2000; Papachristos \& Stamopoulos 2002; Garcia et al 2005). Amer \& Mehlhorn (2006) emphasized the importance of studies with essential oils to unearth their repellency potential. In this regard, all of the four insect species we tested displayed a high sensitivity to trans-anethole and revealed high PRs. However, in terms of the lowest dose yielding the highest efficacy, T. confusum showed the highest sensitivity rate with $95 \%$ PR at $4 \mu \mathrm{L}$ of trans-anethole. Our study should be considered as a preliminary attempt to reveal the potential of trans anethole to be used as a biorational pesticide. Moreover, further researches on such as slow release, encapsulation, and formulation of essential oils and their compounds are crucial to enhance their chance in the development of sustainable and cost-effective plant protection products.

\section{Conclusions}

The results of this study clearly demonstrate that trans-anethole with its efficacy in population suppression and its repellency, in particular, has a strong potential as a bio-pesticide against stored product insect pests. From environmental protection point of view it has also a high potential of use in organic farming, since trans-anethole is thought to be less harmful to environment. It can also be concluded that essential oils have broad spectrum pesticide activity due to the presence of several active ingredients that works with various mode of action than synthetic pesticides. Trans-anethole is found naturally in many plant species of Apiaceae, namely anise, fennel and star anise. There are not many alternatives to synthetic pesticides in controlling stored product pests. Therefore, trans-anethole, one of the few promising alternatives, is very important for controlling storage pests. However, in order to use Trans-anethole in field applications, additional studies on slow-release formulations and on residual remains on treated grains and on other surfaces should be undertaken.

\section{Acknowledgements}

The authors thanks to Prof. Dr. Mevlut EMEKCI for their valuable time and contribution to this study. This study was supported by the Republic of Turkey, Ministry of Agriculture and Forestry, General Directorate of Agricultural Research and Policy.

\section{References}

Alkan M \& Gökçe A (2012). Toxic and behavioural effects of Tanacetum abrotanifolium L. DRUCE (Asteraceae) stem and flower extracts on Sitophilus granarius and Sitophilus oryzae (Col., Curculionidae). Turkish Journal of Entomology 36(3): 377-389

Amer A \& Mehlorn H (2006). Larvicidal effects of varius essential oil against Aedes, Anopheles, and Culex larvae (Diptera, Culicidae). Parasitology Research 99(4): 466-472

Amruta N, Sarika G, Umesha U, Maruthi J B \& Basavaraju G V (2015). Effect of botanicals and insecticides seed treatment and containers on seed longevity of black gram under natural ageing conditions. Journal of Applied and Natural Science 7(1): 328-334 
Bond E J (1984). Manual of fumigation for insect control. FAO Plant Production and Protection Paper 54

Boxall R A (2001). Post-harvest losses to insects - A world overview. International Biodeterioration \& Biodegradation 48(1):137-152

Ertürk S, Yılmaz A, Akdeniz Fırat T \& Alkan M (2017). Trans-anethole ve karbondioksit karışımının Rhyzopertha dominica, Tribolium castaneum ve Sitophilus oryzae'ye karşı fümigant etkisi. Bitki Koruma Bülteni 57(3): 391400

Ferizli A G \& Emekçi M (2010). Depolanmış ürün zararlılarıyla savaşım, sorunlar ve çözüm yolları. TMMOB Ziraat Mühendisleri Odası Ziraat Mühendisliği VII. Teknik Kongresi Bildiriler Kitabı, 11-15 Ocak 2010 Ankara, 2: 579587

Garcia M, Donadel O J, Ardanaz C E, Tonn C E \& Sosa M E (2005). Toxic and repellent effects of Baccharis salicifolia essential oil on Tribolium castaneum. Pest Management Science 61(6): 612-618

Güncan A \& Durmuşoğlu E (2004). Bitkisel kökenli doğal insektisitler üzerine bir değerlendirme. Hasad Dergisi 233: 26-32

Hikal W M, Baeshen R S \& Said-Al Ahl H A H (2017). Botanical insecticide as simple extractives for pest control. Cogent Biology 3(1): 1-16

Ho S H (2000). Response of Tribolium castaneum and Sitophilus zeamais to potential fumigants derived from essential oils of spices. In: Proceedings of the International Conference on Controlled Atmosphere and Fumigation in Stored Products, 29 October - 3 November, Fresno, CA. pp. 119-124

Huang Y, Xing C S \& Hung H S (2000). Bioactivities of methyl allyl disulfide and diallyl trisulfide from essential oil of garlic to two species of stored-product pests, Sitophilus zeamais (Coleoptera: Curculionidae) and Tribolium castaneum (Coleoptera: Tenebrionidae). Journal of Economic Entomology 93: 537-543

Isman M B (2000). Plant essential oils for pest and disease management. Crop Protection 19: 603-608

Juliana G \& Su H C F (1983). Laboratory studies on several plant materials as insect repellents for protection of cereal grains, Journal of Economic Entomology 76: 154-157

Karakoç Ö C, Gökçe A \& Telci İ (2006). Bazı bitki uçucu yağlarının Sitophilus oryzae L., Sitophilus granarius L. (Col.: Curculionidae) ve Acanthoscelides obtectus Say. (Col.: Bruchidae)'a karşı fumigant etkileri. Türkiye Entomoloji Dergisi 30(2): 123-135

Liu Z L \& Ho S H (1999). Bioactivity of the essential oil extracted from Evodia rutaecarpa Hook f. et Thomas against the grain storage insects, Sitophilus zeamais Motsch. and Tribolium castaneum (Herbst). Journal of Stored Product Research 35(4): 317-328

McDonald L L, Guy R H \& Speirs R D (1970). Preliminary evaluation of new candidate materials as toxicants, repellents and attractants against stored product insect. Marketing research report no.882. Agricultural Research Service, US Deparment of Agriculture, Washington, pp.183

Mondal M \& Khalequzzaman K (2010). Toxicity of naturally occurring compounds of plant essential oil against Tribolium castaneum (Herbst). Journal of Biological Sciences 10: 10-17

Mutungi C, Affognon H, Njoroge A, Baributsa D \& Murdock L (2014). Storage of mung bean (Vigna radiate [L.] Wilczek) and pigeonpea grains (Cajanus cajan [L.] Millsp) in hermetic triple-layer bags stops losses caused by Callosobruchus maculatus (F.) (Coleoptera: Bruchidae). Journal of Stored Product Research 58: 39-47

Ndomo A F, Ngamo L T, Tapondjou L A, Tchouanguep F M \& Hance T (2008). Insecticidal effects of the powder formulation based on clay and essential oil from the leaves of Clausena anisata (Willd.) J. D. Hook ex. Benth. (Rutaceae) against Acanthoscelides obtectus (Say) (Coleoptera: Bruchidae). Journal of Pest Science 81: 227-234

Papachristos D P \& Stamopoulos D C (2002). Repellent, toxic and reproduction inhibitory effects of essential oil vapours on Acanthoscelides obtectus (Say) (Coleoptera: Bruchidae). Journal of Stored Product Research 38(2): $117-128$ 
Pimentel M A G, Faroni L R D, Silva F H D, Batista M D \& Guedes R N C (2010). Spread of phosphine resistance among Brazilian populations of three species of stored product insects. Neotropical Entomology 39(1): 101-107

Regnault-Roger C, Vincent C \& Arnason J T (2012). Essential oils in insect control: Low-risk products in a high-stakes world. Annual Review of Entomology 57: 405-424

Shaaya E \& Kostyukovsky M (2011). The use of phytochemicals as fumigants for the control of stored product insect pests. Journal of Entomological and Acarological Research 43(2): 245-251

Shaaya E, Ravid U, Paster N, Juven B, Zisman U \& Pissarev V (1991). Fumigant toxicity of essential oils against four major stored-product insects. Journal of Chemical Ecology 17(3): 499-504

Shaaya E, Ravid U, Paster N, Kostjukovsky M, Menasherov M \& Plotkin S (1993). Essential oils and their components as active fumigants against several species of stored product insects and fungi. ISHS Acta Horticulturae 344, International Symposium on Medicinal and Aromatic Plants, 22 March 1993, Israel, pp. 131-137

Shanker C \& Solanki K R (2000). Botanical insecticides: A historical perspective. India, Asian Agrihistory 4(2): 2130

Taiz L \& Zeiger E (2002). Plant Physiology. Sinauer Associates, Sunderland, Massachusetts, pp. 283-308

Tapondjou A L, Adler C, Fontem D A, Bouda H \& Reichmuth C (2005). Bioactivities of cymol and essential oils of Cupressus sempervirens and Eucalyptus saligna against Sitophilus zeamais Motschulsky and Tribolium confusum Jacquelin du Val. Journal of Stored Products Research 41(1): 91-102

Tapondjou L A, Adler C, Bouda H \& Fontem D.A (2002). Efficacy of powder and essential oil from Chenopodium ambrosioides leaves as post-harvest grain protectants against six-stored product beetles. Journal of Stored Products Research 38: 395-402

Taylor R W D (1994). Methyl bromide- Is there any future for this noteworthy fumigant? Journal of Stored Products Research 30: 253-260

Villers P, Navarro S \& de Bruin T (2010). New applications of hermetic storage for grain storage and transport; Proceedings of the $10^{\text {th }}$ International Working Conference on Stored Product Protection; Estoril, Portugal. 27 June2 July 2010, pp. 446-451

Wang J, Tsai J H, Ding W, Zhao Z \& Li J (2001). Toxic Effects of Six Plant Oils Alone and in Combination with Controlled Atmosphere on Liposcelis bostrychophila (Psocoptera: Liposcelididae). Journal of Economic Entomology 94(5): 1296-1301 